\title{
minutes of the council
}

\section{January 18 and 19, 1981-San Diego, Calif.}

January 18, 1981-9:00 a.m. Present: President White, President-Elect Fleagle, Past President Newton, Secretary of the Council Wallace; Councilors Ackerman, Bierly, Bonner, Booker, Bruce, Hilst, Krishnamurti, Reid, Suomi, and Ward; Commission Chairmen Battan, Baum, Blackadar, Droessler, and Orville; newly elected Councilors Carlstead and Johnson; Executive Director Spengler and SecretaryTreasurer Landrigan.

President White introduced newly elected Councilors Carlstead and Johnson.

\section{Report on Mail Ballots to the Council}

Secretary-Treasurer Landrigan reported that the results of the Mail Ballots to the Council since the last meeting of the Council on October 2-3, 1980, were as follows:

November 18, 1980

Election to Member of candidates recommended by the Admissions Committee on November 10, 1980. Approved.

\section{November 19, 1980}

Minutes of Council meeting held October 2-3, 1980. Approved.

\section{Report of the Ballot Tellers}

Secretary-Treasurer Landrigan gave the report of the Ballot Tellers dated December 29, 1980, which showed that the following individuals were elected to the offices indicated:

Term ends
President-Elect: Richard E. Hallgren

Councilors: David S. Johnson

Edward M. Carlstead

Norman J. Rosenberg

Stanley L. Rosenthal
January 1982 January 1984 January 1984 January 1984 January 1984
James P. Bruce was elected a Councilor by the Council for a three-year term ending in January 1984, as provided in Article $\mathrm{V}$ of the AMS Constitution.

\section{Report of the Planning Commission}

Upon the recommendation of Chairman Battan, it was voted to appoint Eugene Bollay a member of the Planning Commission for a term ending in January 1984, and to appoint Verner E. Suomi a member for a term ending in January 1985.

\section{Report of the Commission on Professional Affairs}

Upon the recommendation of Chairman Baum, it was voted to appoint the following to the boards of the Commission on Professional Affairs:

1) Board of Certified Consulting Meteorologists Howard E. Reiquam, as Chairman for the year ending in January 1982

George E. McVehil, for a term ending in January 1986

2) Board on Industrial Meteorology

Gale F. Hoffnagle, as Chairman for the year ending in January 1982

John A. Bujnoch, Jr., for a term ending in January 1983

David B. Spiegler, for a term ending in January 1984

3) Board for Operational Government Meteorologists Max Mayfield, for a term ending in January 1984

4) Board of Radio and Television Weathercasting Robert T. Ryan, for a term ending in January 1984, and as Chairman for the year ending in January 1982 Bob Breck, for a term ending in January 1984 Dennis W. Feltgen, for a term ending in January 1984

5. Report of the Scientific and Technological Activities Commission

One action item was noted by Commissioner Droessler, i.e., Council consideration of the AMS Statement on "Weather Radar" which has been prepared by the STAC Committee on Radar Meteorology.

Several information items followed:

1) An AMS Statement on Planned and Inadvertent Weather Modification will be published in the January 1981 issue of the BULLETIN.

2) The Commission has received a large number of letters from the membership (many of them from the younger members) volunteering their services on the STAC committees. This attests to the keen interest in and the vitality of the work of the committees.

3) A survey is underway by a Commission-appointed ad hoc committee on the need for a STAC Committee on Polar Meteorology. At the earliest, a recommendation may come before the Council next fall.

\section{Report of the Publications Commission}

Chairman Blackadar discussed the increase in the number 
of pages in publications, the increase in postage rates, and the cost of scientific editing. He suggested that there may have to be an increase in page charges, subscription rates, and dues. It was voted to request the Executive Committee and Executive Director to have available for the October 1981 Council meeting a report on the financing of the Society's publications.

\section{Report of the Education and Manpower Commission}

Chairman Orville discussed the activities of the Board on Women and Minorities and the Board on Meteorological Education in Universities.

Upon the recommendation of Chairman Orville, it was voted to make the following appointments to the boards and committee of the Education and Manpower Commission:

\section{1) Board of Meteorological Education in Universities}

For terms ending as indicated below:

$\begin{array}{ll}\text { Raymond J. Deland } & \text { January } 1983 \\ \text { Henry E. Fuelberg } & \text { January } 1983 \\ \text { Harry L. Hamilton } & \text { January } 1984 \\ \text { David D. Houghton } & \text { January } 1984 \\ \text { Hans A. Panofsky } & \text { January } 1983 \\ \text { James R. Scoggins } & \text { January } 1984 \\ \text { Dayton G. Vincent } & \text { January } 1984\end{array}$

2) Board of Education in Schools and Popular Meteorological Education

For three-year terms ending in January 1984:

Russell L. DeSouza

Herbert S. Lieb

Steven B. Newman

Herbert J. Spiegel

3) Committee of Judges for Undergraduate Awards

Robert L. Gall, as Chairman for the year ending in January 1982

Kerry A. Emanuel, for a three-year term ending in January 1984

4) Board on Women and Minorities

For terms ending as indicated below: Beverly J. Barnhart Gerald W. Grams Margaret A. LeMone

Francis $\mathbf{J}$. Merceret

Mary C. Newton

Steven Richards

Pamela Stevens
The plan provided that there would be 49 drops throughout the United States. Small packages would be made for the benefit of small users who do not require a large circuit but instead a circuit that will not be too costly.

Recessed 1:20 p.m.

Reconvened 2:30 p.m.

\section{Amendments to Code of Ethics}

The Council was of the opinion that only Code Section B. 1.a), b), and c) and Section B. 2 should be deleted, that Section 3 should be retained, that "solicitation" should be defined, and that the five-year period should be reduced.

The Council voted to request the Executive Committee and Chairman of the Commission on Professional Affairs to review the Certified Consulting Meteorologist and Seal of Approval programs and to suggest any changes that appear appropriate in view of the change in the law with respect to learned professions.

10. Appointments to Committees of the Council and Executive Committee

President-Elect Fleagle informed the Council that he had made the following appointments:

1) Robert W. Stewart, Chairman, Sverdrup Gold Medal Committee

2) Morton L. Barad, Chairman, Committee on Fellows and Honorary Members

3) Werner A. Baum, Chairman, Nominating Committee

4) J. Murray Mitchell, Chairman, Awards Committee

\section{Status of Proposed Compendium on Forecasting}

The final report of the ad hoc Committee on the Feasibility of a Compendium on Weather Forecasting was submitted to the Council. After discussion it was voted to obtain from Commission Chairman Droessler and the Committee on Weather Forecasting and Analysis a recommendation with reasons therefore as to the publishing of a Compendium of Forecasting, and to request the Executive Director to give the Council a report on the financial aspects of such a publication at the next meeting of the Council.

\section{Consideration of Proposed Journal of Climate}

After discussion of the report of the ad hoc Committee to Examine the Feasibility of a Journal of Climate, the Council voted, with one dissenting vote, to proceed with 
the publication of a JOURNAL OF CLIMATE, contingent upon obtaining a qualified Editor and Editorial Board, publication to start in 1982, if feasible.

The Executive Committee was requested to work with the Publications Commission and the Executive Director in the selection of an Editor and the Executive Director was requested to explore the feasibility of a merger of a commercially produced climate journal with the new AMS journal.

\section{Relationship of $A M S / N W A$ Certification Programs}

Commission Chairman Battan discussed an exchange of correspondence with the National Weather Association concerning their establishing a certified consulting meteorologist program. The AMS is concerned with the possibility of duplicate programs.

14. Possible Need for Cumulative Author and Subject Indexes for AMS Journals

Executive Director Spengler discussed the cost of producing such indexes.

15. Feasibility of a New Selective Translation Series of Chinese Scientific Literature

Executive Director Spengler was requested to ascertain how much of this material is being translated by the government.

\section{Organization of $A M S$}

It was voted that the inconsistencies that have developed in the published plan be eliminated as soon as possible.
17. Statement on Next Generation of Weather Radar After discussion it was voted to request Commission Chairman Droessler to confer with Commission Chairman Battan and Councilors Ackerman and Suomi, and to make appropriate revisions. President-Elect Fleagle was authorized to adopt or reject the Statement on behalf of the Council.

18. Report of ad hoc Committee to Study the Feasibility of Establishing a Committee on Meteorological Standards

It was voted to accept the report, to thank the ad hoc Committee whose work is completed, and to request Commission Chairman Droessler to turn the report over to the Committee on Atmospheric Measurements where standards focus will remain.

19. Report on Interactive Word and Data Processing System

The Executive Director reported that AMS headquarters may acquire a larger computer and word processing system that would be useful not only in maintaining membership and subscription fulfillment records but also would be useful in editing, publishing and meeting operations.

\section{Next Meeting of the Council}

It was voted to hold the next meeting of the Council in Boston on October 1-2, 1981.

Adjourned 5:45 p.m.

D. F. LANDRIGAN Secretary-Treasurer 
January 19, 1981-6:05 p.m. Present: President Fleagle, Past President White, Past President Newton, Secretary of the Council Simpson; Councilors Bierly, Booker, Bruce, Hilst, Krishnamurti, Reid, and Ward; newly elected Councilors Carlstead, Johnson, and Rosenberg; Commission Chairmen Battan, Baum, Blackadar, and Droessler; Executive Director Spengler and Secretary-Treasurer Landrigan.

\section{Appointment of Commission Chairmen}

It was voted to appoint Owen E. Thompson Chairman of the Education and Manpower Commission for a threeyear term ending in January 1984.

It was voted to reappoint Alfred K. Blackadar Chairman of the Publications Commission for a three-year term ending in January 1984.

\section{Appointments to Boards and Committees}

President Fleagle informed the Council that he had appointed Morton L. Barad Chairman of the 1981 Committee on Fellows and Honorary Members and Robert W. Stewart Chairman of the Sverdrup Gold Medal Committee.

It was voted to appoint James F. Kimpel Chairman of the Board of Meteorological Education in Universities and to extend his term for one year ending in January 1983.

\section{Election of Secretary of the Council}

It was voted to elect Joanne Simpson Secretary of the Council for a term of one year ending in January 1982.

\section{Appointment of Councilors to Executive Committee}

It was voted to appoint David S. Johnson to the Executive Committee for the remaining year of former Councilor Bonner's term ending in January 1982, and to appoint Glenn R. Hilst to the Executive Committee for a term of two years, ending in January 1983.

\section{Commendation of Commission Chairmen}

It was voted to commend the Commission Chairmen for their excellent work as Chairmen of the respective Commissions.

\section{Next Meeting of the Council}

The next meeting of the Council to be held in Boston was set for October 1-2, 1981.

Adjourned 6:20 p.m.

D. F. LANDRIGAN Secretary-Treasurer

\section{THIRD CONFERENCE ON NUMERICAL WEATHER PREDICTION}

\section{April 26-28, 1977 Omaha, Nebr.}

The Third Conference on Numerical Weather Prediction, sponsored by the American Meteorological Society, was held 26-28 April 1977 in Omaha, Nebr. Over 50 papers are arranged under the following topics:

Tropical Phenomena - Global Models • Spectral and Finite-Element Models - Analysis and Initialization - Numerical Techniques - Mesoscale Models • The Boundary Layer and Atmospheric Energetics - Numerical Prediction with Satellite Data

484 pages $\$ 15$ AMS Members $\$ 20$ Nonmembers (add $\$ 2.00$ postage and handling)

Send order and remittance to:

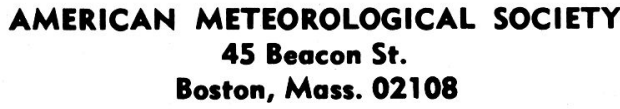

